\title{
POESIA MODERNISTA BRASILEIRA E SUAS AFINIDADES COM O ARCAICO. JoÃo Cabral de Melo Neto e Murilo MENDES
}

\author{
Susana Scramim \\ Universidade Federal de Santa Catarina
}

\section{$O$ arcaico no presente}

Uma das questões mais urgentes dos estudos e da prática envolvendo a crítica literária dos últimos sessenta anos é recuperar sua potência de intervir no tempo presente. Walter Benjamin, antevendo no próprio expressionismo o declínio dessa capacidade de intervenção e de leitura do presente, já assinalava que mesmo o barroco alemão sendo um "viver através", isto é um Fortleben, do expressionismo, esse viver perdurado não possuía a mesma capacidade de intervenção e força coletiva que aquela arte seiscentista produzira em sua sociedade. Entretanto, Benjamin constatava:

\footnotetext{
E aqui o paralelo encontra seus limites. O literato barroco sentia-se totalmente vinculado ao ideal de uma constituição absolutista, apoiada pela igreja das duas religiões. A atitude de seus herdeiros, quando não é hostil ao Estado e revolucionária, caracteriza-se pela ausência de toda ideia de Estado. E finalmente, não devemos esquecer, apesar de muitas analogias, de uma grande diferença: na Alemanha do século XVII, a literatura desempenhou um papel no renascimento da nação, por menos que esta se preocupasse com seus escritores. Ao contrário, os vinte anos de literatura alemã aqui mencionados para explicar a renovação do interesse pelo Barroco correspondem a um período de decadência, ainda que decadência produtiva e preparatória de uma nova fase. (Benjamin, 1984, p.78)
}

A força em negativo que Benjamin destaca no expressionismo é compreendida como produtora de uma nova época histórica, capaz de ler no presente sua potência de reconhecimento da verdade histórica. Ainda no mesmo estudo crítico sobre a força do barroco e seus efeitos no presente, Benjamim destacará que a busca pelo autêntico deverá concentrar-se na pesquisa do descontínuo do tempo, para nele encontrar a sua verdade. Cabe ao crítico, aquele que prevê os fenômenos e os analisa como imagens dialéticas, ler a história sob a perspectiva descontínua e, com isso, libertar o objeto histórico do fluxo da história contínua, para fazê-lo "ressignificar" e encontrar sua verdade, seu presente, ou ainda, seu instante de uma "reconhecibilidade".

Ler com os pressupostos do tempo contínuo faz com que o resultado encontre no objeto o seu passado e o seu futuro, o antes e o depois. Contudo, a sua pré e pós-história não são alcançadas no tempo contínuo, pois essas categorias não respeitam a ordem cronológica dos acontecimentos e, sim, as afinidades internas entre os objetos, qualquer 
que seja a distância entre as épocas que as separam. Dessa maneira, Benjamin não aproxima o drama barroco, em termos de pré-história, ao movimento que o antecedeu cronologicamente (a tragédia renascentista), mas ao diálogo socrático e, nesses mesmos termos, sua pós-história não é o teatro classicista, e, sim, o drama expressionista.

Tal posição crítica permite encontrar no arcaico algo que possa, de modo incisivo, revivendo-o, intervir no presente, produzir diferença. O que importa nesse modo de produzir novos sentidos para as mesmas coisas é a sua potência de identificação de sentidos autênticos para o presente e não propriamente o caráter "velho" do antigo nos objetos de leitura em oposição à atualidade dos tempos. E disso decorrem as questões: $\mathrm{O}$ que conduz a crítica e os estudos literários ao âmbito dos estudos antropológicos? Como refletir e analisar a passagem, tomada aqui como o "limiar entre" - a passagem franca que vai e retorna -, o que é claramente reconhecido como moderno para aquilo que é arcaico, e, portanto, também reconhecido nas sociedades ocidentais como não moderno?

Em sua conferência recentemente lida no XXVII encontro da Associação Nacional de Pós-Graduação em Letras e Linguística, o grupo de professores que discute, analisa e propõe diretrizes e orientações para a pesquisa e o ensino em nível de pós-graduação em Letras na universidade brasileira, realizado entre 10 e 13 de julho de 2012, Raúl Antelo, assessor da área de Letras junto ao CNPq, relembrava aos professores presentes naquele congresso que há uma necessidade vital para a crítica do presente, que é a de recuperar o sentido da tarefa com o qual ela foi investida, o que quer dizer, em outras palavras, que a verdade que toda ciência busca, e, especialmente, na área das humanidades, será encontrada na investigação do passado. Entretanto, ao chamar para si essa tarefa para a crítica, reivindica a quinta tese sobre a história de Walter Benjamin:

\begin{abstract}
A verdadeira imagem do passado perpassa, veloz. O passado só se deixa fixar, como imagem que relampeja irreversivelmente, no momento em que é reconhecido. "A verdade nunca nos escapará" - essa frase de Gottfried Keller caracteriza o ponto exato em que o historicismo se separa do materialismo histórico. Pois irrecuperável é cada imagem do presente que se dirige ao presente, sem que esse presente se sinta visado por ela. (Benjamin, 1994, p. 224)
\end{abstract}

Ainda em sua exortação Antelo conjuga a reflexão de Benjamin à de Giorgio Agamben, quando o filósofo, igualmente discutindo o uso e a existência do método nas investigações científicas, detecta que uma das formas de revigorar e dar sentido à tarefa da crítica é retomar o conceito de Georges Dumézil, de ultra-história ${ }^{1}$. Antelo destaca e

1 Agamben, Giorgio. Signatura rerum. Sul metodo. Torino, Bollati Boringhieri, 2008, p. 91-93. Dumézil, Georges. Mito y epopeya III. Historias romanas. Trad. Sergio M. Baez. México. Fondo de Cultura Económica, 1996, p.14. 
esclarece o sentido desse conceito citando a introdução do volume sobre histórias romanas, de Dumézil, no qual a ultra-história é definida nesses termos:

\begin{abstract}
no soy, ni pretendo ser o no ser, un estructuralista. Mi esfuerzo no es el de un filósofo, sino, conscientemente, el de un historiador: un historiador de la más antigua historia y de la franja de la ultrahistoria a la que es posible pretender acceder razonablemente; es decir, que mi esfuerzo se limita a observar los datos primarios en dominios que sabemos están genéticamente emparentados, y luego, mediante la comparación de algunos de estos datos primarios, mi esfuerzo se remonta hasta los datos secundarios que son sus prototipos comunes. Todo ello sin ideas preconcebidas al principio y, al final, sin la esperanza de que tales datos resulten universalmente válidos. (...) Y en cuanto a los tiempos que preceden a estos documentos, sólo conozco las estructuras que resultan de su comparación. Ninguna estructura se ha impuesto $a$ priori ni por extrapolación y, cuando advierto cierta semejanza con otros datos, inicio la exploración de una cantera comparativa sin saber de antemano lo que allí encontraré". (Dumézil, 1996, p.14. apud Aantelo)
\end{abstract}

As questões pelas quais esta proposta de leitura é interpelada decorrem dessa formulação, exemplo disso são as perguntas que se elaboram: O que o presente ultrahistórico tem a nos dizer? Que tipo de imposição visando uma atualização crescente no campo da ciência moderna deve ser tomada como tarefa crítica, isto é, transformada por nossas práticas como o agora de uma reconhecibilidade específica, na qual "a verdade está carregada de tempo a ponto de explodir"? De acordo com a quinta tese de Walter Benjamin sobre a história: "um presente que não é uma transição, mas um limiar em que o tempo se mantém parado" poderia nos levar a pensar se um intervalo fornece o "momento do despertar"? Aquele mesmo que liberta a história para o presente e "dinamita a época", arrancando-a da continuidade reificada do tempo homogêneo?

\title{
A poesia modernista brasileira e suas relações com o arcaico
}

É instigante refletir e tentar articular a relação de algumas obras poéticas gestadas sob a égide do moderno na poesia brasileira com elementos arcaicos da cultura ocidental. Em sua busca por um sentido para a sua poesia, essas obras encontram-se muito mais ao nível de uma "pré-história" do que plenamente identificadas com a modernidade que as viu nascer. Questões que interessaram aos poetas do modernismo brasileiro, em especial, a relação entre a vida e a morte da poesia, entre a linguagem e a voz, entre o cérebro e o sangue, decorrem de uma operação de leitura dos poetas modernos, na qual deslocam até suas obras o puro gozo advindo da prática do ritual celebratório e intelectualizado derivado da lírica amorosa da poesia do sul da Europa, com sua "gioi che mai non fina". O que se coloca, portanto, como desafio à tarefa de sua poesia, é um tipo de busca ou 
experimentação com as afinidades que podem surgir do enfrentamento entre Eros e Thanatos, entre o desejo e o luto, entre o objeto perdido e o objeto ausente. Sobre tal jogo de proposição de afinidades, Giorgio Agamben acentuará:

\begin{abstract}
A herança que a lírica amorosa do século XIII transmitiu à cultura europeia não é tanto certa concepção de amor como o nexo Eros-linguagem poética, o entrebescamen do desejo, fantasma e poesia no topos outopos do poema. E se se quiser buscar, seguindo os rastros exemplares de Spitzer, um trait éternel da poesia romance, é certo que precisamente nesse nexo poderia proporcionar o paradigma capaz de explicar tanto o trobar clus, como "tendência especificamente romance até a forma preciosa", como a análoga tensão da poesia romance até uma autossuficiência e um absoluto do texto poético. O trobar é clus porque é em seu fechado círculo pneumático onde se celebra a união sem fim do desejo e de seu objeto, enquanto que a concepção tipicamente medieval do caráter fantasmático do amor encontrou sua resolução e seu saciamento em uma prática poética. No transcurso de um processo histórico que tem em Petrarca e em Mallarmé suas etapas emblemáticas, esta essencial tensão da poesia romance deslocará seu centro do desejo ao luto e Eros cederá a Thánatos seu impossível objeto de amor para o recuperar através de uma fúnebre e sutil estratégia, como objeto perdido, enquanto o poema se converte no lugar de uma ausência que tira, entretanto, dessa ausência sua autoridade específica. (Agamben, 2007, p. 223-224)
\end{abstract}

O trobar clus, tomado como uma "tendência romance" que se desdobra em "forma preciosa" e a "tensão da poesia romance" enfrentada como o avesso de uma mesma moeda, isto é, a da "autossuficiência" e do "absoluto poético", leva-nos a refletir de modo intenso e extremo sobre a obra de Murilo Mendes e João Cabral de Melo Neto. Em ambas reconhece-se a busca pela vida, portanto, uma "tendência romance", onde imperiosa é a necessidade de comunicabilidade que acontece mediante o contato com a morte tendência à "autossuficiência" e ao "absoluto" - empreendidas pela prática poética dos dois autores. Entretanto, o ponto de origem é o da morte, ou seja, o do silêncio que se impõe ao poeta como um problema e algo candente a ser provido, como um turbilhão dinâmico que surge imprevisivelmente na correnteza do rio da história e se faz presente em cada objeto. Problema esse, o da morte como ponto de origem, que irá caracterizar algumas obras produzidas sob os influxos do barroco e também da modernidade, e que para Walter Benjamim tem o sentido da emergência de algo, pois, para o filósofo alemão, a "origem não designa o vir-a-ser daquilo que se origina, e sim algo que emerge do vir-a-ser e da extinção". (Benjamin, 1984, p.64)

Pode-se aqui falar de um tipo de estratégia artificiosa para criar um movimento do luto ao desejo, do silêncio à comunicabilidade, numa espécie de reversão perversa da prática da melancolia, especialmente se o analista leva em consideração que os primeiros livros desses poetas empenham uma busca por algo que está ausente e não propriamente perdido. Cabral inaugura seu percurso literário poético com o livro Pedra do sono, conjunto de textos em que a imagem dos olhos que procuram por algo faz a poesia acontecer em 
muitos dos poemas do livro. Em "Poema", poema inaugural de Cabral, o primeiro verso diz: "Meus olhos têm telescópios/ [...] longe de mim mil metros" (Melo Neto, 2003, p. 43). E no poema "Os olhos", os versos dizem: "Todos os olhos olharam:/o fantasma no alto de escada,/ [...] (Os olhos ainda estão muito lúcidos.)" (idem). Qual a força que essa imagem desencadeia? O corpo procura por algo, os olhos é que praticam a ação, mas o próprio poema descobre que aquilo que se procura não é encontrado porque os "olhos estão muito lúcidos". Nos poemas que se seguem, a imagem dos "olhos" dá lugar ao "pensamento" que nasce "dentro da perda da memória", conduzindo o poema para esse lugar da linguagem em estado de larva, que, segundo Giorgio Agamben, é o lugar da infância (Agamben, 2005, p. 135). No poema de Cabral, "Infância", lê-se: "Sobre o lado ímpar da memória/ um anjo da guarda esqueceu/perguntas que não se respondem" (ibidem, p. 46). Assim, a poesia prossegue em seu acontecimento no poema. Em "A poesia andando", frequentemente lido como um poema no qual o poeta engenheiro antecipa sua aparição ${ }^{2}$ - porque constrói versos que materializam o pensamento como o traçado de avenidas iluminadas -, "Os pensamentos voam/[...] Entre mim e eles/estendem-se avenidas iluminadas/que arcanjos silenciosos/percorrem de patins" (idem), desse modo, o poema ratifica que o pensamento se move na perda da memória, "os pensamentos amam e se afogam/em marés da águas paradas" (ibidem, p. 47). O poeta anseia a fonte do poema, sua musa - "as amadas" -, "mas elas não sabem onde me encontrar" (idem). Em "As amadas", a poesia continua a sua recusa em aparecer diante dos olhos, “- Por que as nuvens baixas/pesando nos meus olhos?/ Onde as amadas para minha espera?" (idem). Nesse tipo de melancolia ao revés - a busca enlutada pelo objeto ausente - o que se ausenta é a ideia de vida, para que nessa relação o desejo e o objeto apareçam: a poesia.

A mesma melancolia encontra-se às avessas em um poeta como Murilo Mendes, cujo livro inaugural, de poemas escritos entre 1925 e 1929, inicia-se com as noções de jogo e exílio. O poema "Canção do exílio", da seção "O Jogador de Diabolô", envolve um ponto relacional em que o brinquedo infantil promove a associação da linguagem larvar da infância, de alguma maneira muito próxima à morte, ao estado em que o risco e o medo de morrer são iminentes semelhante ao lamento entoado nas canções de exílio. O desejo e seu objeto encontram-se unidos, no entanto, sabe o poeta que este objeto está irremediavelmente perdido, mas que a canção lhe garante a possibilidade de encenar esse encontro. O lamento da canção se converte pela paródia na constatação dessa

2 O crítico Luiz Costa Lima ressaltaria em sua análise de Pedra do sono que nele já "se entremostra o elemento de que partirá o salto a ser dado pelo Engenheiro". Cf. Lima, Luiz Costa. Lira e anti-lira. Mário, Drummond, Cabral. Rio de Janeiro: Civilização Brasileira, 1966, p. 247. 
impossibilidade que insiste em existir. Disso decorre outra hipótese de leitura, identificada por alguns na poesia de Murilo Mendes como uma melancolia derivada de sua adesão ao catolicismo $^{3}$, sua nostalgia por um paraíso além vida, o qual somente seria alcançado na morte. No poema "O menino sem passado", o estado de ter ficado "sem tradição sem costumes nem lendas/ estou diante do mundo/ deitado numa rede mole / que todos os países embalançam” (Mendes, 1994, p. 89), proporciona-lhe a possibilidade do movimento realizado justamente por esse estado de ter ficado sem tradição. Tal posição relacional da poesia moderna, em que Thanatos assume a função de mediador entre Eros e seu objeto, numa passagem do desejo ao luto, foi intensamente cultivada na obra de grandes pensadores do final do século XIX e começo do século XX.

Em toda a obra de Walter Benjamim, esse será um potente motor para a elaboração de seu pensamento, na formulação de uma pergunta que a modernidade insistiu em não responder: o que é vida? Qual o conceito que poderia abarcá-la? Que tipo de movimento relacional se estabelece na arte entre vida e morte? Preocupações, sem dúvida, de Benjamin, porém contemporâneas à sua modernidade europeia, desdobradas, por sua vez, por Rainer Maria Rilke nas suas Elegias do Duino, e mesmo por Mallarmé, para quem a situação de um naufrágio era a condição de sua poesia, cuja proposição está extremadamente em consonância com a ideia de declínio da poesia do fim do século XX. Além deles, ressalte-se que todo o trabalho filosófico desenvolvido por Giorgio Agamben tem dado especial atenção a esse problema, vale dizer, o de como a noção de morte sobre a qual se erigiu a modernidade ocidental pode ser transformada em novas formas de vida, e o de como fazer a linguagem de Thanatos dar lugar à voz de Eros. Não se trata mais de questionar e reivindicar um conceito de vida, já que não há como restituir valor a uma vida já deteriorada, porém, cabe ainda pensar como essa vida danificada pode originar formas de vida.

Giorgio Agamben, da mesma maneira que Walter Benjamin, tentará formular e especular sobre essa nova linguagem com a poesia. Para o pensador alemão, Hölderlin, Baudelaire, Stefan George, Brecht e Kafka serão os autores que potencializarão sua busca;

\footnotetext{
3 Mario de Andrade, o primeiro a julgar a poesia pós-vanguardista de Murilo Mendes como fruto do Essencialismo, em 1939, na resenha que escreve do livro "A poesia em pânico", ressalta a confusão de sentimentos que o modo de Murilo Mendes de compreender a religião católica causa em sua própria poesia, isto é, Mário atribuía a essa maneira de compreender o catolicismo de Murilo Mendes como uma "seiva de perigosas heresias. Não tenho a intenção de insinuar [que] seja insincero este poeta; me inquieta apenas a sua complacência com o moderno, e a confusão de sentimentos....” (Andrade, apud Mendes, 1994, p.34). Manuel Bandeira, em seu Apresentação da poesia brasileira, também atribui à sua poesia um certo caráter herético, ressaltando que o culto operado por Neri e Mendes “afronta o ridículo; incorpora-o.”(ibidem, p. 36)
} 
já no caso do pensador italiano, além dos mesmos autores, incluem-se obras de outros que lhe propiciam elaborar seu pensamento sobre as formas de vida do tempo presente: de Mallarmé, Rilke, Giorgio Caproni, Ossip Mandelson.

Sobre essa posição relacional frente a Thanatos e Eros, e ao analisar a obra de Murilo Mendes no que diz respeito ao seu despertar para uma concepção de mundo derivada de sua conversão à religião católica - o que lhe proporcionara um estado afetado e melancólico frente à vida terrestre condenada à ausência do paraíso -, Raúl Antelo, em "Murilo, surrealismo e religião" e "Visão e pensamento. Poesia da voz", o primeiro escrito para ser lido em conferência de abertura do Colóquio "Passagens e impasses do poético" (Universidade Federal de Santa Catarina, nov. 2001), e o outro, publicado em 2006, no livro coletivo do projeto de Cooperação Acadêmica entre a Universidad de Sevilla e a Universidade Federal de Santa Catarina, Crítica e ficção, já demonstrou que a malinconia, proporcionada pelo entre-guerras, afetava a poesia de Murilo, principalmente quando publica no Jornal Dom Casmurro, em setembro de 1937, o artigo "Poesia católica":

Por isso, nessa compreensão de autêntica malincolia de entre-guerras, como a chamaria Jean Clair, Murilo Mendes conclui que a religião é moderna, porque "detesta o velho mas conserva o antigo", daí que, para Murilo, restaurar a poesia em Cristo não seja bem "desprezar a matéria, bater no peito e enfiar-se na sacristia, mas justamente o contrário: ela equivale a "sair da sacristia". (Antelo, 2006, p.10)

No entanto, esse afetar era compreendido por Murilo Mendes como uma passagem entre os estados da alma, não como ponto de chegada de um estado a outro, mas como passagem. O que me parece poder ser estendido ao desejo de João Cabral pelo encontro com a vida a partir da constatação de uma ausência, da constatação da secura da vida e das coisas. Em Murilo Mendes, a constatação vem da figura do menino que "ficou sem tradição", como diz o seu verso; e em Cabral deriva dos versos do poema "A palo seco", os quais demonstram que o seu cantar se faz em solitário e é "cantar num deserto devastado pelo sol” (Melo Neto, 2003, p. 247). Exemplo dessa constatação relacional também é a intensa luz do deserto devastado pelo sol de Cabral, em paralelo com os retratos-relâmpagos de Murilo Mendes, os quais são produzidos a partir de um efeito de luminescência do flash, de modo que ele faça aparecer o fantasma com sua potência de dizer em sua disposição para o mundo.

A questão que importa a esta leitura aqui empreendida é a de como isso move a poesia desses dois poetas, e como eles podem lembrar-se dos vestígios do mundo antigo e dar-lhes uma nova existência, da morte à vida, tendo para isso que negar o velho e revisitar 
o antigo, o que no caso de Murilo Mendes significa, também como católico, sair da sacristia, portanto, praticar uma outra religião: a do moderno, pois o moderno para ambos os poetas encontra seu sentido no mundo arcaico. Uma questão de cunho literário histórico do modernismo no Brasil orienta também esta leitura: a da maneira com a qual o modernismo artístico brasileiro compreendeu, mediante a feitura de suas obras, a modernidade como uma equação diferenciada de sua modalidade europeia, portanto, com o sentido do reconhecimento de que a morte é um passo, compreendido como uma passagem, para outro modo, uma outra forma de vida nessa mesma modernidade.

É importante estudar e verificar nas obras de Murilo Mendes e nas de João Cabral, consideradas como moderna poesia brasileira, um movimento da constatação de uma ausência, a morte, em sua coexistência e transformação em formas de vida, isto é, da modernidade e com seu signo de morte para outra modalidade de poesia, de outra forma de inserção na história literária. Nesse sentido, seria possível inclusive retomar os julgamentos severos, porém, agudos, de Mario de Andrade e de Manuel Bandeira, naquilo que reconhecem, conforme a análise do primeiro, que "Murilo Mendes conseguira provar com expressão dura, infalível, mesmo genial, que entrando para o Catolicismo, não se entrega ao recurso de uma paz, porém, se dera conscientemente à grandeza de mais uma luta" (Andrade, apud Mendes, 1995, p. 34), e, para o segundo, o poeta Manuel Bandeira, que Murilo Mendes se sente ele mesmo e, ao mesmo tempo, o seu duplo, pois "luta entre um homem acabado e um outro que está andando no ar". O seu maior desejo é voltar para o Princípio, "que nivela a vida e a morte, a construção e a destruição"; a sua maior inveja, Adão, "único homem que foi ao mesmo tempo mãe, pai, irmão, esposo e amante" (ibidem, p. 36-37).

A morte na poesia de Murilo Mendes tem a força de um ditado, o de anunciar o tempo anacrônico, ou, como dirão Mário de Andrade e Manuel Bandeira, o tempo da eternidade, com isso derivando um forte enfrentamento com a ideia de modernidade como destruição. A temporalidade anacrônica em Murilo Mendes, mas não somente nele, tem a força de arrancar às circunstâncias, marcadas pela factualidade histórica, o tempo do acontecimento, talvez a isso se referisse Manuel Bandeira quando reconhecia na poesia de Murilo um lirismo que se constrói numa conciliação de contrários, algo que o próprio Murilo chamou de "lirismo dialético".

A temporalidade com a qual a poesia de Murilo Mendes se manifesta não é épica nem mítica, nem mística, mas, paradoxalmente, essas instâncias atravessam simultaneamente sua poética, criando uma ideia de tempo em que a modernidade aparece como 
momento de uma ordenação imanente ao mundo da vida humana. Nessa ordenação, conforme Giorgio Agamben já assinalara em suas investigações sobre a modernidade, e, em especial em $O$ reino e a glória, a filosofia política e a teoria moderna do sujeito, materializada na teorização sobre a soberania, e no triunfo da economia e do governo, tomam na modernidade uma dimensão jamais vista, acarretando a submissão de qualquer aspecto da vida social aos desígnios de uma governabilidade econômica. A poesia tem se dedicado, em todo esse movimento de "ordenação imanente ao mundo", a tentar desordenar o pensamento. Movida por esse desejo faz uso da negatividade absoluta, enfrentando sem nenhuma piedade e nenhuma tentativa de consolo o chamado para pensar outras formas de vida, outras formas de modernidade. Nesse uso da negatividade absoluta, um sujeito positivo não poderia aparecer como substituto para divindades e reinados objetos de questionamentos e rejeições. E é com esse objetivo que a subjetividade "impessoalizada" passa a ser um procedimento da arte. E esse sujeito será sempre uma busca por conhecimento não racional, já que na teoria do sujeito apresentada por Agamben o "Eu" situa-se numa zona de limar e não-conhecimento, pois abdica de suas propriedades para comover-se. Agamben acolhe o que Simondon definia como comoção, isto é, o meio através do "qual entramos em contato com o pré-individual. Emocionar-se significa sentir o impessoal que está em nós, fazer experiência com o Genius como angústia ou alegria, segurança ou temor” (Agamben, 2007, 19). Nada mais próximo do que Mário de Andrade percebe na poesia de Murilo Mendes: “...tais conquistas não nos dão sono, antes nos proporcionam o encontro do arcanjo com que iremos brigar a inteira noite... Talvez não seja ainda oportuno estudar este amor e lhe fazer a exegese, mas não hesito em confessar que poucas vezes a nossa poesia atingiu tais acentos de paixão e de angústia... era natural que tantos desequilíbrios assim juntados pusessem a arte em fuga e a poesia em pânico" (Andrade, apud Mendes, 1995, p. 34). Em Estâncias, Agamben completaria que a autêntica intenção poética não se propõe ao alcance de um conhecimento, mas se transforma em uma modalidade de pensamento sobre formas de vida. E para exemplificar o que diz, se refere a Hölderlin, para quem a poesia sempre constituiu um problema no interior do qual ele cogitava o retorno à invenção engenhosa dos antigos, o que poderia the conferir a possibilidade de ensiná-la e de lhe restituir a unidade da própria palavra despedaçada (Agamben, 2007, p.13).

Interessa sobremaneira a esta leitura o quanto esse movimento que inverte a direção de um conceito de modernidade pensado como conquista, ordenamento e administração 
da vida esteve no cerne das preocupações da poesia de alguns poetas do modernismo brasileiro, em especial, na poesia de Murilo Mendes e João Cabral de Melo Neto.

Aquilo que mais intrigava a poesia de Murilo Mendes era a relação entre arte e angústia, arte e paixão, portanto, a relação entre a linguagem e a morte, não num sentido propriamente de convergência operada por uma síntese dialética, mas por uma constatação da coexistência dos extremos, e, nesse sentido, é importante relembrar a admiração que Murilo Mendes nutria por Adão quando revela que seu maior desejo é voltar ao Princípio, "que nivela a vida e a morte, a construção e a destruição"; a sua maior inveja, Adão, "único homem que foi ao mesmo tempo mãe, pai, irmão, esposo e amante". Esse era o ponto de inflexão que João Cabral e ele compartilhavam, e que por sua vez os conectava com uma tradição poética circunscrita pela negatividade absoluta, como, por exemplo, a poesia de Mallarmé e a tradição e gosto pelo arcaico cultivado por certa poesia espanhola, inclusive a vanguardista. Tal relação com esse mundo arcaico ibérico, ou, ainda, com esse mundo mediterrâneo destruído, soterrado e destinado ao inconsciente pela história dos homens e pelos processos de racionalização da vida humana, vem à tona não somente nos poemas dos dois poetas; vem à tona com igual força na correspondência trocada entre eles.

Em seu estudo sobre a presença da cultura espanhola na poesia de ambos os poetas, Ricardo Souza de Carvalho observa que, enquanto em um a Espanha aparece como aquela que "configura um projeto de poesia", no caso da poesia de Cabral, no outro, ela aparece como algo que "se conforma ao projeto" de uma poesia já existente. Cabral é um jovem poeta quando conhece pessoalmente Murilo Mendes, no entanto, o mundo que Cabral encontrará soterrado no mediterrâneo ibérico tornar-se-á vida para sua poesia, mediante as afinidades que o poeta será capaz de articular e identificar nesse sítio arqueológico em que se constitui o inconsciente moderno da poesia brasileira modernista. A configuração de uma poesia se sustentaria, mesmo no caso da poesia de Cabral, como projeção de algo já existente, também anteposta em sua materialidade e sobre a qual a ação do poeta irá concentrar-se para recriar esse mundo de afinidades. Essas afinidades serão construídas a partir daquilo que se encontra morto, e, nesse sentido, esse mundo mediterrâneo soterrado e arcaico é que se encontra à espera da ação de um poeta.

Ricardo Souza de Carvalho, ainda em sua pesquisa sobre a relação entre a poesia de Cabral e de Murilo Mendes com a Espanha, indica também a forte relação que alguns poetas do modernismo brasileiro terão com a cultura ibérica. Dá destaque, entretanto, à mobilização feita por muitos escritores brasileiros em oposição manifesta aos regimes totalitários fascistas e de como sua posição contra Franco, na Espanha, prepara um núcleo 
em torno do qual a poesia de Cabral e Murilo se organizaria. É interessante observar o quanto a tradução operada por Manuel Bandeira e Drummond da poesia espanhola e mesmo a produção poética de ambos reflete essa posição política de adesão à arte espanhola em sua forma de vida, em tempos de repressão e guerra civil. E de como o uso da forma poética, ou seja, do gênero "romance", pode ter exercido a função de marcar a uma posição política - o que configura sem dúvida o uso do gênero poético como um ponto de reflexão crucial na análise da poesia de Murilo Mendes e de Cabral. Em 1954, ano de publicação de Contemplação de Ouro Preto, a poesia de Murilo Mendes se veste com o figurino, com as vestes da poesia espanhola, seguindo com isso o conselho de Cabral para que a poesia brasileira se revestisse com baladas e romances, inserindo no livro os poemas "Romance das igrejas de Minas" e "Romance de Ouro Preto". Contudo, é interessante sublinhar aqui o quanto os versos de Quaderna, o gênero quaderna via, evocam o roman paladino, dos cantares de gesta, cujo teor é uma boa conversa em troca de um bom vinho. Isso revela não uma configuração a algo, mas uma conformação de uma afinidade soterrada entre a cultura mediterrânea, o transnacionalismo da moderna cultura brasileira e suas outras formas de vida na modernidade. No entanto, tal círculo de afinidades ultrapassa em suas práticas a tradução da poesia espanhola.

Os dois poetas se conhecem em 1940, quando Cabral viaja com a família para o Rio de Janeiro; Murilo Mendes, nessa ocasião, o apresentará a Carlos Drummond de Andrade e ao círculo de poetas que se reunia no consultório de Jorge de Lima. Em 1947, Cabral vai para Barcelona como vice-cônsul. E, em 1948, inicia-se uma intensa e interessante correspondência entre os dois.

Em recente pesquisa junto ao acervo de João Cabral de Melo Neto na Fundação Casa de Rui Barbosa, iniciei a leitura das cartas escritas por Murilo Mendes a João Cabral. Nessa pesquisa, pude constatar o quanto essa relação com o mundo arcaico da cultura mediterrânea atravessou a feitura das obras de ambos os escritores.

\section{A(s) correspondência(s)}

Em carta escrita do Rio de Janeiro, em 6.V.1948, Murilo conta a Cabral: "Tive a revelação da Espanha aos 20 anos quando li pela primeira vez Du sang, de la volupté et de la mort, de Maurice Barrès". Livro esse que se dedica a estudar a maneira como a dedicação ao culto da morte na Espanha e na Itália fez desse ritual um ponto de inflexão ao artístico. E pede a Cabral três livros de Vicente Aleixandre: La desctrucción o el amor", Sombra del paradiso, 
Espadas como lábios. Todos esses livros, vale observar, estão hoje depositados no acervo do escritor, em Juiz de Fora.

Em 1949, em carta a Cabral, Murilo se refere a um possível ensaio que Cabral estaria escrevendo sobre um toureiro. Conta-lhe que tem com ele uma plaquette de Michel Leiris, "Miroir de la tauromachie", com desenhos de A. Masson. Oferece-a a Cabral. Murilo Mendes até então nunca tinha ido à Espanha. Depois, quando efetivamente conhece o país, entre 1953 e 1955, irá lamentar-se a vida inteira de saudades, e irá compará-la nesse momento com o sul da Itália. O elemento comparável nessa relação é o arcaico inerente a essas culturas. A busca pelo arcaico, pelo resíduo, pelo não comunicativo, mas comunicável, marca esse ponto e inflexão entre a linguagem, aquilo que somos, e o mundo, aquilo que nos olha. Essa busca atravessa a poesia de Murilo e Cabral. Perscrutar a luz intermitente dos vagalumes, índice do arcaico, é também a mesma busca da luz que emana dos retratos-relâmpagos de Murilo.

Maria Betânia Amoroso, no ensaio "Retratos-relâmpagos. Despedida e comemoração", publicado na revista de Estudios Portugueses, em 2010, analisa a maneira como esses retratos individuais de artistas do mundo ocidental são um "novo tecido", uma nova maneira de escavar as camadas superpostas do tempo, oferecendo, com isso, segundo a autora, uma "nova roupagem" também para o "gênero memória”, que em Murilo Mendes será "atravessada pela constante presença da ideia de biblioteca, bibliografia e bibliofilia" (Amoroso, 2010, p. 10). Isso nos leva à compreensão de modernidade como mais uma camada do sítio arqueológico no qual se conforma a história carregada de resíduos que somente serão ressignificados pelo modo de aproximação dessa desordem, que é singular e orientada por forças não controladas racionalmente. Disso também deriva as comparações entre as culturas do mediterrâneo que os poetas Cabral e Murilo Mendes operam com a cultura brasileira e sul-americana.

Em primeiro de janeiro de 1955, de Bruxelas, Murilo escreve a Cabral. Relata ao amigo que passou três meses na Sicília. Faz comparações com a Espanha no que as une: o ponto de vista da paisagem e a miséria das populações do interior e que, acrescentamos aqui, nada diferem filosoficamente da paisagem brasileira. Em um "P.S.", Murilo complementa que depois de ter vivido dois anos na Europa, o que mais lhe impressionara fora o Museu de Pintura Antiga da Cataluña, o Museu de Frederico Mares, de Toledo, as pinturas de El Greco e de Veláquez, e, acima de tudo, a pintura românica da Cataluña, e também Ravenna e Torcello. 
A bordo do "Paolo Tocanelli", em 22 de janeiro de 1957, Murilo escreve a Cabral durante sua viagem a Las Palmas, ali recordando a Espanha e escrevendo entre parênteses: (Trago sempre a Espanha comigo)". Convida o casal Stella e João a visitá-los na Itália e tenta convencer o amigo dizendo-lhe: "Não pensam em dar um pulo na Itália? Há muita coisa sêca na Itália, João: monumentos na Toscana e na Úmbria. Mesmo na luxuriosa Sicília, lá para o interior das terras, muitas vezes lembrava-me a Espanha. Mas, de qualquer forma, no recesso de meu espírito, no mais íntimo meu, é Toledo que vive”. Essa afinidade soterrada sob as muralhas de Toledo, para Murilo Mendes, conformava-se à sua compreensão do processo histórico, porque o entrecruzamento entre culturas - a cristã, a moura e a judaica - ali efetivado, era uma demonstração "da superposição de camadas de tempo" (Mendes, 1995, p. 1135), conforme pode-se ler em Espaço espanhol, ou seja, do tempo da história que é destruição, morte, superposição e redescoberta.

E mesmo num poema escrito antes, ou seja, em Tempo espanhol é possível perceber essa reflexão sobre a modernidade, do tempo histórico como destruição, morte, superposição e redescoberta:

\author{
Morte situada na Espanha \\ (La claridad - Sevilha) \\ Distingo perto as ruínas de Don Juan, \\ Advertência didática da morte. \\ Morte que fascina o espanhol \\ Trazendo-lhe a vida à tona. \\ Morte para o espanhol: odiada força \\ Que extingue o livre-arbítrio e seu diamante, \\ A honra vertical e a marca de cada um.
}

Morte:

Objeto adormecido no átomo

E que sabe explodir a Bomba.

Nasceste mineral, a ele regressarás.

Morte: rito decisivo

Onde o touro e toureiro se consomem.

Morte de Sevilha, Córdova, Toledo.

Morte do Museu românico da Catalunha.

Operário e estudante espanhóis,

Mortos que sois na flor da greve!

Tua morte; morte dos amigos essenciais; minha morte.

Morte da Espanha; morte de qualquer objeto;

Morte que explode na mão do universo - criança. 
$[\cdots]$

O real explode com a morte.

A contenção espanhola da morte.

Explode em fogo e fim.

Explode a morte agredida pelo espanhol.

Explode o silêncio espanhol da morte.

Morte: tempo físico que explode

Largando a pele da memória,

Tempo da memória que explode

Substantivamente.

(Mendes, 1994, 620)

\section{A religião moderna. A morte e suas formulações em desordem}

Murilo Mendes reencontra-se com a Espanha em 1952, quando viaja efetivamente ao país cuja cultura ele cultivara desde a juventude, tanto no aprendizado da língua ${ }^{4}-$ Murilo Mendes tinha aulas de espanhol -, quanto com o viver junto através dos livros e o apreço por sua arte de vanguarda e antiga. Em sua coluna do Suplemento de Letras e Artes, de 12 de setembro de 1948, do jornal $A$ manhã, Murilo Mendes relacionava a pintura de Ismael Nery e a moderna pintura brasileira ao substrato cultural arcaico.

Os mais recentes estudos críticos de pintura demonstraram o encadeamento do processo da
modernidade através dos séculos. Sabemos hoje que muitos elementos importantes da arte de
Picasso, Braque, Bonnar e outros estão contidos pelo menos em germe nos primitivos
medievais, nas pinturas bizantinas e mesmo em documentos mais remotos. Conhecemos agora
a impressionante modernidade de Bosh, surrealista no século XVI; Arcimboldo abriu caminho
para Salvador Dal. E como explicar a súbita inclinação do mundo das artes para o esquecido El
Greco - um verdadeiro coup de foudre - se não fora a sua modernidade patente? (Garcia, 1990,
p.304)

Antes de ver a Espanha como imagem visível e física, o poeta já a compreendia como dotada de uma "modernidade patente", bem como a pintura e a poesia modernas envolvidas num movimento anacrônico frente ao primitivo. Entre 1966-1969, registra em seu livro Espaço espanhol o que lhe deixou impresso na retina: o contato com a geografia cultural.

A pintura antiga catalã é altíssima, ao nível de criação estética que nos deu os "primitivos" flamengos e italianos. Meu primeiro encontro com essa pintura, no longínquo ano de 1952, causou-me um choque do que não regressei até hoje (p. 1168).

${ }^{4}$ Araújo, Laís Corrêa de. Murilo Mendes ensaio crítico, antologia, correspondência. São Paulo Perspectiva, 2000, p.356. 
Se for possível compreender a relação do humano com o visível, próximo à maneira como James Joyce elabora seu livro Ulisses, torna-se evidente o quanto de reencontro há no ato de ver, ou seja, o quanto de experiência há na imagem. Na cena em que Stephen Dedalus, ao olhar o mar, encontra-se com os olhos de sua mãe, é possível encontrar uma teoria da incontornável cisão do que é visível: o que nos é dado a ver é porque podemos ver a nós mesmos em espelho, assim sendo, no duplo separado pela imagem é que nos reencontramos.

\begin{abstract}
Inelutável modalidade do visível (ineluctable modality of the visible): pelo menos isso se não mais, pensado através dos meus olhos. Assinaturas de todas as coisas estou aqui para ler, marissêmen e maribodelha, a maré montante, estas botinas carcomidas. Verdemuco, azulargênteo, carcoma: signos coloridos. Limites do diáfano. Mas ele acrescenta: nos corpos. Então ele se compenetrava deles corpos antes deles coloridos. Como? Batendo com sua cachola contra eles, com os diabos. Devagar. Calvo ele era e milionário, maestro di color chi sanno. Limite do diáfano em. Por que em? Diáfano, adiáfano. Se se pode pôr os cinco dedos através, é porque é um grade, se não uma porta. Fecha os olhos e vê. (Joyce, 2003, p.51-52)
\end{abstract}

E a isso acrescentaria Georges Didi-Huberman: "O que vemos só vale - só vive - em nossos olhos pelo que nos olha. Inelutável, porém, é a cisão que separa dentro de nós o que vemos daquilo que nos olha" (1998, p.29). Os olhos são o espelho pelo qual vemos e somos vistos e isso é algo contra o qual não podemos lutar: a cisão daquilo que é visível.

A pintura espanhola e sua cultura passam para Murilo Mendes e para João Cabral a indicar o suporte de uma perda, e é desde aí que essa cultura produz a visão, pois ela reflete, olha, concerne e persegue. A pintura espanhola torna-se um emaranhado de atmosferas, paisagens e mortes pressentidas a devolver-lhes a imagem de si mesmos, de seu país e de sua modernidade. A superfície de que é feita essa paisagem cultural indica e dissimula ao mesmo tempo a profundeza que a habita.

\title{
Murilo Mendes escreve em Espaço espanhol:
}

Goethe escreveu: ‘o órgão pelo qual compreendi o mundo é o olho'. Creio que em Granada esta palavra se realiza na sua força (Mendes, 1994, p.1180).

Mais adiante se espanta frente ao rochedo que separa a cidade de Ronda em duas e escreve:

Rilke, medusado, demorou-se aqui algumas semanas. Mas que ação pode exercer o texto sobre a Coisa irremovível? (Mendes, 1994, p.1182).

Ou ainda, quando fala do catolicismo na Espanha: 
[...] no limite do afeto pessoal e do tradicionalismo cristalizado [...] expressão teocrática duma sociedade tendendo sempre ao imobilismo político-social... (Mendes, 1994, p.1162)

Diante disso, não se está muito distante dos modos de ser da modernidade brasileira, especialmente do modo pelo qual João Cabral construía as correlações entre a paisagem andaluza e a pernambucana.

\section{Relação entre morte e vida, entre o arcaico e o presente}

O livro História do olho, de George Bataille, mais do que se constituir do relato de alguns jogos eróticos dos personagens Simone, Marcela e o narrador, é o relato da história de um objeto, afirmava Roland Barthes em 1963, no n.195-196 da revista Critique, dedicado à obra de Bataille. Nessa história, o objeto vai sofrendo uma série de metamorfoses nas quais se obedece a um rigoroso processo de derivação por correspondências. Barthes chega a se referir a uma série metafórica composta pelo relato. O que a série metafórica do olho devolve-nos ao olhar? Sabemos que Georges Bataille se interessava pelas forças arcaicas do inconsciente e concretizou muito desse interesse em diversificadas e intensas pesquisas sobre modalidades de vida social. Com isso, não se está muito distante das preocupações artísticas e existenciais de Murilo Mendes e de João Cabral de Melo Neto, nem da moderna cultura brasileira.

Nas camadas superpostas da história da modernidade no Brasil residem elementos da arte mediterrânea, tanto a que está ali em função de sua utilidade na empresa da colonização portuguesa quanto a que restou como diálogo ou interface do mesmo processo civilizador. Interessa para essa leitura do arcaico na moderna poesia brasileira o resíduo deixado pela pintura de Joan Miró e Rafael Alberti. Ainda inserida no que se entende aqui por conformação de uma afinidade soterrada entre a cultura mediterrânea e o transnacionalismo da moderna cultura brasileira está a relação com a vanguarda artística espanhola; exemplo disso é o fato de Olívia Guedes Penteado ter tido em sua coleção um quadro de uma "bailaora" espanhola de Miró.

O trabalho com as fontes arcaicas da cultura marcou a pintura de Joan Miró e por isso interessou aos poetas Cabral e Murilo Mendes esse tipo de pesquisa. Ambos escreveram sobre o pintor catalão. Em seu ensaio sobre Miró, Cabral ressalta e valoriza um tipo de pintura em que 
o objeto pintado não estava e nenhuma relação com os limites da superfície que o continha. Estava tão solto no espaço como uma estátua qualquer. A parede de caverna ou a madeira do retábulo eram mais bem o vazio. Paralelamente, a superfície - definida por seu limites - existia, como elemento essencial, em outro tipo de arte: na decoração. $\mathrm{Na}$ pintura decorativa, o objeto (quando acontece, ou aparece; quando não se esvazia em sua estilização, quando não se apaga em favor da superfície) não pretende agir por si, como o bizonte ou o santo do primitivo. Ele se anula na sintaxe onde se inscreve, na superfície ativa ao serviço da qual o puseram. (Melo Neto, 2003, p.691)

Cabral encontra o valor numa certa autonomia do objeto/sujeito da pintura sem, entretanto, haver uma ação propriamente autônoma desse objeto/sujeito, uma vez que ele se insere na sintaxe do objeto, em sua história, tal qual a derivação metafórica em série que Roland Barthes enxerga em História do olho, de Georges Bataille. Cabral procura "outra forma de composição que devolva à superfície aquele sentido antigo que seu aprofundamento numa terceira dimensão destruiu completamente”. (Ibidem, p. 695) Para ele, Miró foi quem respondeu a essa procura, mas antes dele Cabral relembra que Baudelaire foi dos autores que mais violentamente subverteram esse conceito de beleza de perturbadora atmosfera contemplativa, a que faria chamar-se de réve de pierre.

Quando Murilo Mendes faz reviver mediante a luz do retrato-relâmpago a imagem de Joan Miró, o que se destaca é o modo como o pintor "organiza a infância futura" e “exorciza o lado mecânico do nosso tempo" (Mendes, 1995, p.1223).

Miró declara que não pode separar a poesia da pintura. Rompe a linha convencional do discurso realista, criando a sigla, o número plástico, a alusão (Idem).

\section{Estudos para os retratos-relâmpagos produridos pelo olhar}

O poema "Estudos para uma bailadora andaluza" foi publicado em Quaderna, livro dedicado a Murilo Mendes, escrito entre os anos de 1956-1959, quando Cabral estava de volta à Espanha, depois de responder a um inquérito político no Brasil em que lhe acusavam de subversão. Arquivado o inquérito, a pedido de um promotor público, e depois de prolongada a estadia no Recife, Cabral foi restituído a suas funções no Itamaraty e assim designado para a função de cônsul adjunto em Barcelona. Contudo, fazia parte dos objetivos da sua missão, fazer pesquisas históricas no Arquivo das Índias de Sevilha, por isso, é nessa cidade, e não em Barcelona que ele vai viver entre os anos de 1956 e 1958. Nesse mesmo momento, o isolamento diplomático da Espanha, recomendado pelos EUA desde o final da Segunda Guerra, perde seu sentido político e assim são retomadas a 
relações diplomáticas, em 1950. O Brasil, entretanto, já tinha restaurado suas relações com a Espanha em 1947, talvez por nosso passado comum, ou por nosso pendão autoritário, ou, ainda, por nosso professo anticomunismo materializado no catolicismo, mas não foi isso que aproximou João Cabral, que não era anticomunista e tampouco católico, da Espanha. O que estabelece as relações entre a poesia de Cabral e a cultura espanhola, particularmente a andaluza, não é por certo o catolicismo e o anticomunismo, mas antes a busca por uma soberania artística, uma autonomia para o sujeito/objeto na qual o elemento principal da pintura/poesia seja a sua inserção numa certa sintaxe da imagem, algo que ele encontrava nas formas residuais dos afetos da cultura andaluza e na pintura vanguardista e também em sua pesquisa sobre o arcaico de Joan Miró, conforme demonstrado aqui anteriormente, e que estão diretamente relacionadas em suas formas residuais à cultura do nordeste brasileiro.

Gostaria de destacar, nesse sentido, que a autonomia com a qual a crítica enxergou a poesia de Cabral não passaria de uma consecução de uma soberania artística. Deve-se ainda ressaltar que essa soberania, justamente porque não é autonomia, não depende de fatores técnicos, materiais ou territoriais, mas antes das relações de cumplicidade, comunicação e interação que logra estabelecer o sujeito criador com os receptores de seu envio. E conforme já nos explicou Georges Didi-Huberman, em sua conferência sobre o flamenco na Bienal del Flamenco, em Sevilla, em 2005: “A soberania da arte não é, de modo algum, a soberania do artista, e sim a de uma experiência humana (e, por isso mesmo, social) que, no caso do flamenco, está condicionada pelo contexto (não somente espacial, mas também simbólico), no qual se vê o baile ou se escuta o canto (um teatro à moda italiana não é a mesma coisa que uma peña flamenca)".

O poema de Cabral "Estudos para uma bailadora andaluza" já tem no título uma indicação do tom, assemelhando-se ao modo como o guitarrista e o cantaor introduzem, ou seja, como executam a salida para o cante. No lugar da construção de um retrato, ou de um estudo para um retrato, o que de antemão se coloca ao leitor é a postulação de uma experiência singular e ao mesmo tempo múltipla: os "estudos". O diálogo de Cabral com a pintura moderna espanhola toma vulto já no início, e há ainda a contraposição entre a pintura do Retrato de bailarina española (1921), do catalão Joan Miró, e seu poema "Estudos para uma bailadora espanhola". 


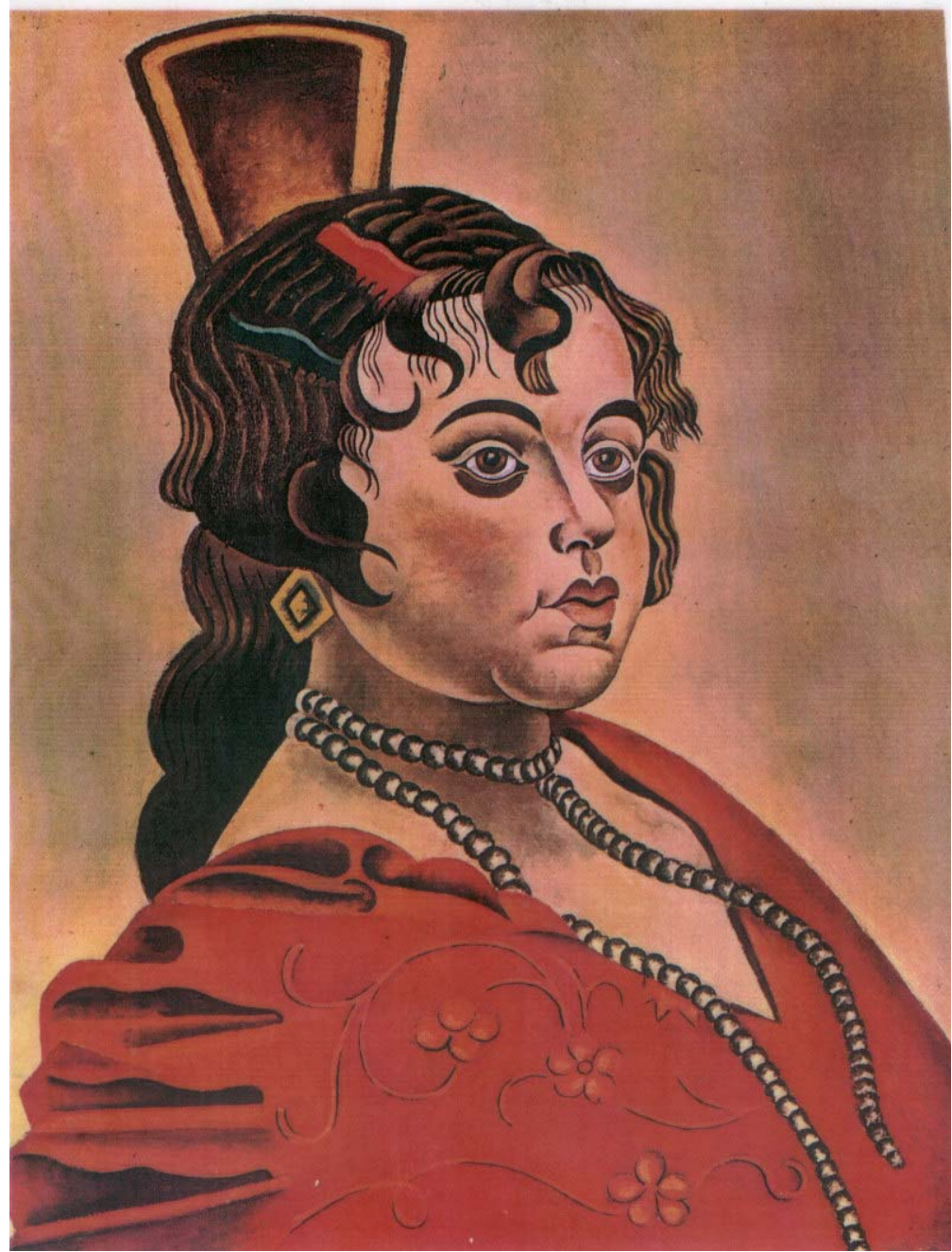

Retrato de bailarina española, 1921, óleo, Museu Picasso de Paris.

Diante da observação do quadro de Miró, em sua comparação com o poema de Cabral, tendo em vista toda a fundamentação teórica prevista para esta leitura, surge a pergunta: Qual a relação que se configura entre o olho e o que é olhado?

O quadro "Retrato de una bailarina española", de Joan Miró, reelabora em 1921 vários elementos da pintura medieval catalã. $O$ destaque dessa reelaboração é a metamorfose da bailarina antiga em imagem de bailaora, já que na Idade Média não poderíamos falar propriamente em uma arte “del flamenco". No entanto, há um destaque operado por Miró, que interessa problematizar no processo de metamorfose do medieval para o moderno. Na bailarina de Miró, que não é propriamente uma bailaora, os olhos com contornos exagerados, amendoados e cercados por sobrancelhas em arco, mas que estão esfumaçados, oferecem destaque à figura humana que olha de modo singular para o pintor.

Há mais do que o diálogo entre Cabral e Miró nessa pintura, há superposições de camadas de tempo, tanto no poema quanto na pintura. $O$ pintor catalão escava o terreno 
soterrado da história e começa a tecer as afinidades com os objetos encontrados e o presente, que aparecem na repetição dos olhos ovalados e bem destacados, como se gozassem de uma autonomia em relação ao resto do corpo da bailarina, mas que estariam plenamente inseridos na sintaxe desse corpo, uma vez que se adequam ao nariz de perfil nítido e boca também de desenho ovalado característicos da pintura medieval catalã em sua soberania. Cabral também irá buscar na cultura medieval espanhola procedimentos que lhe permitiriam produzir sua arte soberana. A relação com o trabalho de Gonzalo Berceo é indicadora desse movimento, que acontece no uso frequente, por parte de João Cabral, da estrofe de quatro versos, e também da retomada que faz da concepção “estudos”, ao aludir, em presença, ao quadrivium, e, por ausência, ao trivium ${ }^{5}$.

João Alexandre Barbosa (2001 - Publifolha) nos chama a atenção para o uso, por parte de Cabral, da estrofe chamada cuaderna via, definida como "um tipo de estrofe usada principalmente nos séculos 13 e 14 e composta de quatro versos alexandrinos de uma só rima" (Barbosa, 2001, p.59), especialmente nos textos de raízes populares do poeta pernambucano e que se prestam ao gênero romance da poesia tradicional espanhola, dedicadas aos relatos e canções de gesta e encenadas em um ambiente celebratório de boa conversa e bom vinho. Contudo, se de alguma forma podemos relacionar a opção pela cuaderna via como parte de uma reelaboração da ideia dos "estudos", mais ligado ao quadrivium, isto é, ao ensino do método científico por meio de quatro ferramentas relacionadas à matéria e à quantidade, a saber, a aritmética, a geometria, a música (harmonias) e astronomia, por outra, a relação com o culto humanista no uso do verso de Gonzalo Berceo indica a reflexão sobre os estudos na modalidade do trivium, já que Berceo esteve sempre preocupado com a comunicabilidade de seus textos, porque usava a retórica como técnica de persuasão e seus poemas tinham o objetivo da catequese, tendo sido dirigidos a pessoas de origem humilde. De modo muito complexo, portanto, o poema "Estudos sobre uma bailadora", de João Cabral, apresenta-se à leitura entre seu desejo de

5 Etimologicamente, trivium significa "o cruzamento e articulação de três ramos ou caminhos". Esse grupo de disciplinas incluía a lógica (ou dialética), a gramática e a retórica. As artes do trivium teriam como objetivo prover disciplina à mente, para que esta encontre expressão na linguagem, especialmente no que se refere ao estudo da matéria e do espírito. De acordo com definições clássicas, a matéria teria como característica essencial o número e a extensão, temas analisados respectivamente pela aritmética e pela música, bem como pela geometria e astronomia (ou astrologia clássica). Segundo esta mesma definição, o espírito teria como caractere essencial o número.O quadrivium, etimologicamente o cruzamento de quatro ramos ou caminhos, está voltado para o estudo da matéria, por meio do domínio das seguintes disciplinas: aritmética (a teoria do número); em música (a aplicação da teoria do número), em geometria (a teoria do espaço) e em astronomia (a aplicação da teoria do espaço). No âmbito do quadrivium, a música é entendida como o estudo dos princípios musicais, tais como a harmonia, não podendo ser confundida com a música instrumental aplicada (uma das sete belas-artes). O objetivo destas artes ditas "da quantidade" era prover meios e métodos para o estudo da matéria, sujeitos a aprimoramento no âmbito das disciplinas ditas superiores. 
destaque e o de pertencimento, de subida e de enraizamento, entre o cosmo da organização poética o seu derivado caos; entre todas essas questões, esse poema tenta encontrar o seu modo de existir.

$\mathrm{Na}$ primeira parte do poema, apresenta-se o ritmo da música segundo o qual a bailadora se move, trata-se de um palo flamenco, a siguiriya.

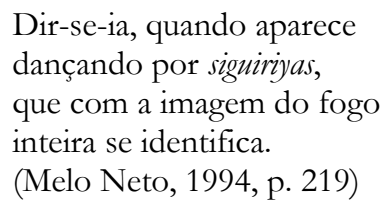

Ricardo Molina, poeta espanhol e estudioso da arte do flamenco, em Mundo y formas del cante, afirma que as coplas antigas e autênticas não possuem pretensões artísticas, sejam elas literárias ou teatrais. Representam a queixa direta da alma e nada mais. A siguiriya é derivada desses tipos de coplas. Diversos outros tipos de cantes admitem expressar frivolidades do cotidiano, mas à siguiriya está vedada essa possibilidade. A siguiriya é o grito do homem ferido por seu próprio destino, admitindo que esse grito seja a "flama" da angústia. A solenidade do baile se manifesta já em sua salida, caracterizada por um largo paseo. Pode ser bailada, indistintamente, por homens e/ou mulheres, mas o "temperamento forte" é prérequisito. Uma das grandes bailaoras de siguiriyas foi a hispano-argentina Pilar López, irmã da tão ou mais famosa "La Argentinita", Encarnación López Júlvez. As irmãs, amigas de García Lorca, Rafael Alberti e outros artistas pertencentes à Geração de 27, fogem da Espanha por causa da Guerra Civil, e durante os anos mais duros da ditadura franquista viveram em exílio em alguns países da Europa e no Marrocos, viajaram por alguns países da América Latina e, inclusive, fizeram uma estadia no Brasil. La Argentinita morre em Nova Iorque, em 1945, mas sua irmã Pilar López estaria de volta à Espanha na década de 1950.

Julio Castañon Guimarães, em "Cabral falando", resenha ao lançamento do CD com gravações de leituras de poemas de Cabral e de Murilo Mendes, lidos por seus próprios autores, demonstra o quão interessante é para o leitor ouvir um poeta lendo seu próprio poema, no sentido de que se fazem presentes outras "possíveis marcas peculiares que imprimiu à leitura (ênfase em determinadas palavras, pausas maiores ou menores, e assim por diante) que, inclusive, podem constituir pelo menos indícios para algum tipo de compreensão ou interpretação dos textos”. (GUIMARÃES, 2002, p. 304). Além disso, nesse específico CD das leituras de Cabral e Murilo, a dicção dos dois poetas é bastante 
distinta uma da outra, e, como, assinala Julio Castañon, "essas distinções podem ter a ver não apenas com peculiaridades pessoais, mas com as características da poesia de cada um e com a noção que cada um tem de sua própria poesia”. (Ibidem, p. 305).

Gostaria de apresentar alguns minutos de um vídeo fruto de uma montagem com a voz de Cabral lendo o poema dos estudos sobre a bailaora e a imagem de Pilar López dançando uma signiriya. Pelos destaques dados aqui à importância de se estar atento ao som desses poemas lidos por seus próprios autores e, acrescento, aos gestos da bailaora encenando seu grito de angústia, a montagem de imagens superpõe as camadas de uma temporalidade que se desejou entrelaçada: a do poema e a do baile em um vídeo com a bailaora de flamenco Pilar López em uma siguiriya com a voz de João Cabral lendo o seu poema. Nesse vídeo, serão observados os gestos Pilar López, a cor de seu vestido e sua expressão facial e, na voz de Cabral, os destaques feitos a cada parte de seu poema siguiriya, os acentos e pausas, dando passagem à sua soberania artística (ver vídeo em anexo).

Cabral era um homem que não gostava de música e tinha elogiado a passagem do ritmo ao equilíbrio na pintura de Miró. O que não quer dizer que não tivesse elaborado uma reflexão a respeito do ritmo e da poesia. O ritmo tem efeito simbólico, engendra o que não tem vontade mediante a vontade de modo instintivo, já afirmou Nietzsche (Nietzsche, 2005, p.63). E é nesse sentido que se pode cogitar o ritmo como o pulsar do sangue que faz do poema uma forma de vida, e não a melodia, o que me parece mais apropriado no caso de Cabral. Em Herodiade, Mallarmé oferece ao poema a possibilidade de alcançar uma forma de vida outra, pois sua dança, o seu ritmo, entendida no seu "mistério" e inserida no mundo simbólico lhe confere essa potência. Paul Valéry, em seu Filosofia da dança (dedicado a ninguém menos que La Argentinita), entenderia a dança como uma maneira de criar perguntas e respostas através do corpo em movimento. Para Valéry, a dança é a "poesia geral da ação", que é ação filosófica plena, pois seus gestos têm a potência interrogativa sobre o ser.

A primeira abordagem crítica que a poesia de João Cabral de Melo Neto recebeu foi a resenha de seu primeiro livro de poemas, Pedra do sono, escrita por Antonio Candido, em 1943. Nesse texto, Candido compreende a poesia de Cabral como "tão autonomamente construída" e à escuta da "VOZ(?) do cisne mallarmeano sempre viva, a ponto de vir ressoar na última geração da nossa literatura" (Candido, 2000, p. 18). Análise precisa que detectou as tendências dessa poesia fez com que a crítica não conseguisse passar muito ao longe do diagnóstico de Candido. Desde João Alexandre Barbosa até Benedito Nunes e Luiz Costa Lima, ao analisarem a poesia de Cabral, os críticos remetem-se a Mallarmé e a Paul Valéry. 
Entretanto, lendo recentemente a pesquisa de um professor de literatura brasileira na Universidade de Leiden, Ruud Ploegmaker, chamou-me muito a atenção a sua hipótese de trabalho, quer seja, a de que há na poesia de Cabral um herói. Ploegmaker também observa a relação do poema "Estudos para uma bailadora andaluza" com a teoria da dança de Mallarmé, e demonstra como se apresenta e qual a função das heroínas ou heróis no poeta francês, inserindo-se com isso na fina e aguda tradição metafísica na qual a função da poesia é entendida em relação análoga à função do poeta no mundo. O poeta nessa tradição é compreendido como um elo que liga o mundo dos deuses e o dos homens. No entanto, nessa tradição, é a voz do poeta que se sobrepõe à do herói. Isso se pode constatar na leitura que Heidegger opera do poema "Dichtermut", "Coragem do poeta", de Hölderlin. O interessante na leitura de Poegmaker é que quando ele detecta a figura do herói/heroína na poesia de Cabral, já estabelece a singularidade da poesia do poeta pernambucano em relação à do poeta francês. Na poesia de Mallarmé, o autor controla o herói e o que o olhar do herói vê é a impessoal incorporação de um cosmo. Essa tradição está inserida num mundo permeado pela discursividade. Na poesia de Cabral, pelo menos como ela é lida aqui, essa função da poesia não está vinculada exclusivamente à voz do poeta; há em lugar disso um frágil e tenso equilíbrio entre o poeta, o herói e o leitor. Os princípios de interação e cumplicidade, princípios que prevêem a comunicação poética atuando no poema com força dominante.

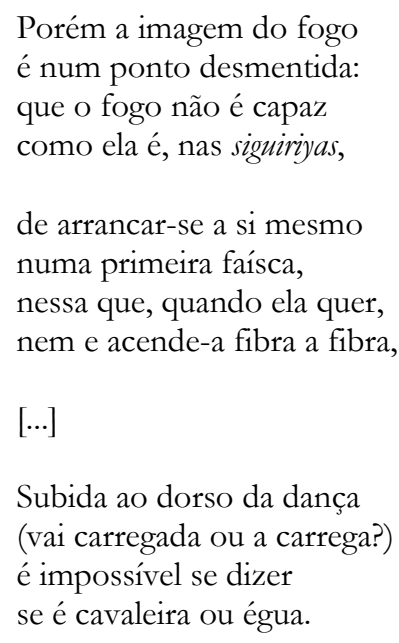

(Melo Neto, 2003, p. 219-220)

No entanto, e aqui as ambivalências começam a se instalar, a heroína não tem discurso, sua linguagem é movimento, itinerante. Daí a contiguidade entre a heroína deste poema e o 
herói, de presença preponderante na poesia da Cabral, o nordestino, e com os outros heróis, os toureiros. São heróis providos de uma outra voz ou ainda de uma outra posição frente ao mundo. Essa voz na poesia de Cabral libera um não saber (o do homem sem discurso, sem qualidades) e o libera segundo o ritmo do compás da siguiriya, no corpo da bailadora, e de acordo com o ritmo do desafio e interação no corpo do cantador nordestino.

$$
\begin{aligned}
& \text { Quando está taconeando } \\
& \text { a cabeça, atenta, inclina, } \\
& \text { como se buscasse ouvir } \\
& \text { alguma voz indistinta. } \\
& \text { (Melo Neto, } 2003 \text { p. } 221 \text { ) }
\end{aligned}
$$

O poema trata de um saber anacrônico, aquele do poeta que fala por canções, ele executa movimentos antigos, todavia, esses movimentos sofrem a ação do tempo, eles estão cortados, e o poeta escreve canções que não cantam.

Nesse sentido, uma questão se faz urgente: o que escutamos quando lemos um poema? E não importa mais o que o poeta vê, porque ele não vê um cosmo e, sim, ouve um caos, esse é o ritmo que lhe chega do arcaico.

Sobre o recurso da alusão e aproximação de um modo de ver em três dimensões, é forçoso tomar em conta para a análise uma gravura de Rafael Alberti, com a qual o poeta andaluz presenteia o casal Murilo Mendes e Maria da Saudade, em 1966, cujo título é Los ojos de Picasso II. 


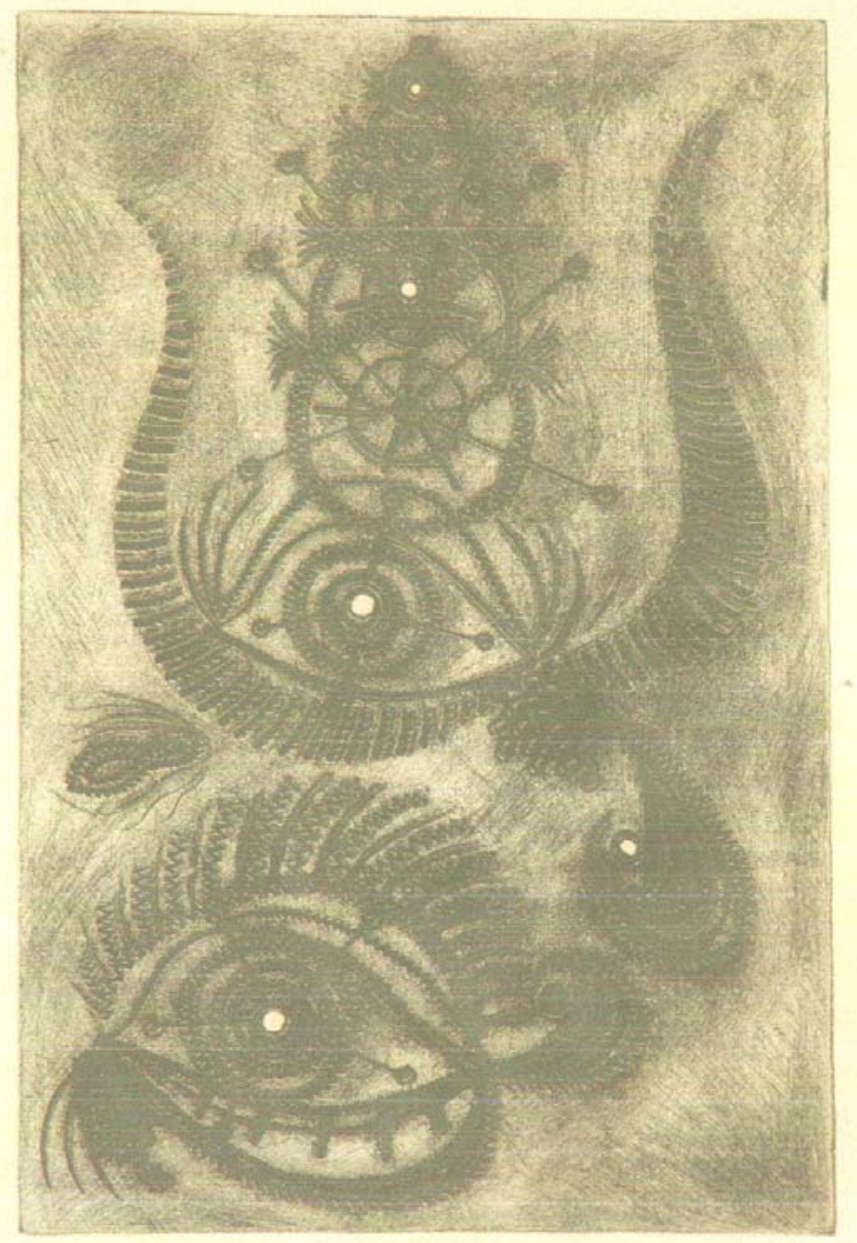

Na gravura, observa-se que o olho está em relação com a figura humana, que já não está pautada pela fisionomia, mas, sim, por um tipo de xenoglossia, já que elementos estrangeiros à representação humana fazem parte da configuração do portal do conhecimento. Esses os olhos estão, sim, medusados, como os de Rilke diante do abismo da cidade espanhola de Ronda, seus contornos precisos agora mantém relação de semelhança com os tentáculos da medusa e às folhas de uma samambaia.

Impossível deixar de retomar nesse momento o já citado História do olho, de George Bataille: uma praça de touros, um orgasmo simultâneo ao desfecho da corrida, quando o 
touro investe contra o toureiro e um dos chifres atravessa o seu olho direito e sua cabeça. Eis a cena:

Granero foi derrubado e acuado contra a cerca, na qual os chifres do touro desfecharam três golpes: um dos chifres atravessou-lhe o olho direito e a cabeça. O clamor aterrorizado da arena coincidiu com o espasmo de Simone. Tendo-se erguido da laje de pedra, cambaleou e caiu, o sol a cegava, ela sangrava pelo nariz. Alguns homens se precipitaram e agarraram Granero.

A multidão que abarrotava a arena estava toda de pé. O olho direito do cadáver, dependurado. (Bataille, 2003, p. 68)

Bataille, remetendo-se a Stevenson, afirmaria nos apêndices para uma futura continuação da História do olho, no verbete "Olho", que o globo ocular é:

guloseima canibal, pois produz uma tal inquietação que não conseguimos mordê-lo. O olho chega a ocupar uma posição extremamente elevada no horror por ser, entre outros, o olho da consciência. (Bataille, 2003, p. 96)

Em seu livro Tempo espanhol (1955-1958), entre tantos outros poemas, inclusive os poemas sobre os poetas antigos espanhóis e pintores da Cataluña medieval, Murilo Mendes, escolhe o poema "Numância" para abrir a coleção. O poema toma uma posição discursiva, em que poesia e pintura colocam-se à escuta de uma voz, ou daquele ditame ou ditado ou, ainda, do dictum, e, assim, no diapasão da xenoglossia, propõe-se à barbarização do evento linguístico e à metamorfose da poesia em pensamento, dispondo-se, desse modo, à escuta de uma voz cujo significado é um ainda não apreensível, mesmo que se reivindique novamente o problema da lição e o do estudo, como o que foi aventado aqui no poema de Cabral "Estudos para uma bailadora andaluza". A xenoglossia é outra possibilidade de poder ver a si mesmo na inelutável cisão do visível, do outro que se constitui a imagem de nós mesmos. E o poema "Numância" se apresenta nessa dualidade do visível.

Numância

Prefigurando Guernica

E a resistência espanhola,

Uma coluna mantida

No espaço nulo de outrora.

Fica na paisagem térrea

A dura memória da fome,

Lição que Espanha recebe 
No seu sangue, e que a consome.

(Mendes, 1994, p. 577)

Cabe ainda investigar as relações entre poesia e resistência apresentadas nesse poema de abertura do livro de Murilo Mendes. Numância é a imagem pela qual Guernica é revista no poema. Além de ser o símbolo nacional hispânico da resistência, é simultaneamente a declaração da impossibilidade do sacrifício, pois os romanos tomam a cidade, matam e escravizam todos seus habitantes. Trata-se de um episódio histórico que retorna a tragédia de Miguel de Cervantes, El cerco de Numancia, com argumento atravessado pelo mito da cidade ibérica de Numancia, que, sitiada pelos romanos comandados por Escipión Emiliano, vê seus habitantes destruírem-se a si próprios e à cidade, no lugar de se renderem ao inimigo, indicando uma forma de vida, uma potência de resistência e de potência passiva. Essa tragédia é retomada por Rafael Alberti em uma adaptação levada à cena em 26 de dezembro de 1937, no Teatro de la Zarzuela, com direção de María Tereza León, e música de Jesús García Leoz, permanecendo com grande êxito em cartaz até 8 de março de 1938. A Guerra Civil espanhola reúne no poema de Murilo Mendes a destruição de Numância e Guernica, da mesma forma que teria sido reunida na iniciativa de Rafael Alberti, para a adaptação da tragédia El cerco de Numancia, de Cervantes. Une essas duas leituras, mais do que a óbvia condição do visível que a destruição da sociedade espanhola pelas mãos de Franco e seus seguidores oferece a essa imagem, o grito de alerta contra a militarização do mundo e a transformação da existência em castração.

Georges Bataille, em artigo publicado na revista Acephale III-IV, chama a atenção para a má leitura que os intelectuais antifascistas fizeram, por sua vez, da representação da tragédia cervantina em Paris, encenada pela companhia de Jean-Louis Barrault, com música de Alejo Carpentier. Bataille destaca que o silêncio do resto do mundo frente ao massacre de Guernica e isso, para ele, era o sintoma de uma posição ocidental a favor da militarização do mundo, e não apenas um evento regionalizado. Denis Hollier, comentando essa análise de Bataille, ainda acrescentaria que Marcel Mauss já havia descrito, em 1936, esse mundo que o ocidente caminhava por realizar, em sua bem conhecida carta a Elie Halévy, em que o alerta para o fato de a tragédia de Numância ser a tragédia da sufocante homogeneização produzida pelo binarismo (diferente do dualismo), que é constitutivo das formações de guerra. (Hollier, 1997, p. 180). Para Bataille, a tragédia é a transformação da morte em elemento comum da vida comunitária entre os homens. No seu artigo, pode-se ler: 
O que há de grande na tragédia de Numância, é que aí não se assiste apenas à morte de um certo número de homens, mas à entrada na morte de uma cidade toda inteira: não são indivíduos, é um povo que agoniza. Está aí o que deve chocar (rebuter) e, em princípio, tornar Numância inacessível, porque o jogo que o destino joga com os homens não pode aparecer à maioria a não ser sob os aspectos brilhantes e coloridos da existência individual.

De outra parte, o que está atualmente no espírito se se fala de existência coletiva é o que se pode imaginar de mais pobre e nenhuma representação pode ser mais desconcertante do que aquela que dá a morte como o objeto fundamental da atividade comum dos homens, a morte e não a alimentação ou a produção dos meios de produção. Sem dúvida uma tal representação se apoia sobre o conjunto da prática religiosa de todos os tempos, mas o uso predominou de olhar a realidade da religião como uma realidade de superfície. O que na existência de uma comunidade é tragicamente religioso, em formal estreitamento (étreinte) com a morte, deveio a coisa a mais estranha para os homens. Ninguém pensa mais que a realidade de uma vida comum — vale dizer, da existência humana — depende da colocação (mise) em comum dos terrores noturnos e dessa sorte de crispação extática que a morte espalha. Assim a verdade de Numância é mais difícil ainda de apreender que aquela da tragédia individual. Ela é a verdade religiosa, é dizer, em princípio, o que a inércia dos homens que hoje vivem rejeita.

A idéia de pátria — que intervém como componente da ação dramática — não tem senão uma significação exterior se se a compara a essa verdade religiosa. Quaisquer que sejam as aparências, os símbolos que comandam as emoções não são daqueles que servem a figurar ou a manter a existência militar de um povo. A existência militar exclui mesmo toda dramatização dessa ordem. Ela está fundada sobre uma negação brutal de toda significação profunda da morte e, se utiliza seus cadáveres, é para fazer seus viventes marcharem com maior retidão. A representação a mais trágica que conhece é a parada e, dado que exclui toda depressão possível, ela está na incapacidade de fundar a vida comum sobre a tragédia da angústia.

É nesse sentido que a pátria, condenada a fazer sua a brutal pobreza militar, está longe de bastar à unidade comunial dos homens. Ela pode devir em certos casos uma força de atração destruindo as outras possibilidades, mas sendo essencialmente composição de força armada, não pode dar àqueles que sofrem sua atração nada que responda às grandes avidezes humanas: porque subordina tudo a uma utilidade particular, ela deve, ao contrário, à pena seduzidos, fazer entrar seus amantes no mundo inumano e totalmente alienado das casernas, das prisões militares, das administrações militares. No curso da crise que deprime atualmente a existência, a pátria representa mesmo o obstáculo o mais grave a essa unidade da vida que - é preciso dizê-lo com força — não pode ser fundada a não ser sobre uma comum consciência do que é a existência profunda: jogo emocional e dilacerado da vida com a morte.

Numância que não é senão a expressão atroz desse jogo, não podia pois tomar mais sentido para a pátria que para o indivíduo que sofre só. Ora, Numância tomou de fato para aqueles que assistiram ao espetáculo um sentido que não tocava nem ao drama individual nem ao sentimento nacional, mas à paixão política. A coisa se produziu a favor da guerra da Espanha. (Bataille, 2009, p.197).

Não pode passar despercebido ao leitor brasileiro que, em Espaço espanhol, ao remeter-se a Soria, cidade espanhola situada na região das ruínas de Numância, Murilo Mendes reencontra, entre 1966 e 1969, nas recordações de sua visão da superfície da paisagem castelhana, a imagem de si no outro e o temor pela militarização e homogeneização da paisagem subjetiva interior, sua, da poesia e da sociedade brasileira.

Descortino o horizonte de Numância, deserto, incomensurável a olho nu. Observo a vegetação rasa onde um ou outro resto de coluna se salienta, algum marco a assinalar o episódio da grande resistência aos romanos; recuando nos séculos descubro a atualidade de Numância na sua gesta épica. Resistência; não deveria ser esta a palavra de ordem universal? Resistência à agressão, à lei do lobo ou da raposa, a qualquer violência, fardada ou não. (Mendes, 1994, p. 1144) 
É esse medo, temor, de que a morte seja considerada ponto regulador da vida comunitária na modernidade ocidental, a ênfase desta leitura, tanto na poesia de Murilo Mendes, em sua tentativa de releitura da nova religião, a modernidade, que não se coaduna com o seu catolicismo, quanto no interesse de Cabral pelo princípio de indiferenciação entre homem e natureza, sujeito e objeto, próprios de um pensamento religioso antigo, em que a morte é compreendida como possibilidade de (re)visão e não como reguladora da organização social.

\section{Referências bibliográficas}

AGAMBEN, Giorgio. Nudità. Roma: nottetempo, 2009. . Signatura rerum. Sul metodo. Torino: Bollati Boringhieri, 2008.

Che cos'è il contemporaneo. Roma: Nottetempo, 2008. (Tradução brasileira O que é o contemporâneo e outros ensaios. Chapecó: Argos. 2009.) . Il regno e la gloria. Milano: Neri Pozza Editore, 2007.

. Profanações. Trad. de Selvino Assman. São Paulo: Ed. Boitempo, 2007. . Estâncias. Trad. de H. Burigo. Belo Horizonte: Ed. UFMG, 2007. . A linguagem e a morte. Trad. de H. Burigo. Belo Horizonte: Ed.

UFMG, 2006. . L'Aperto. L'uomo e l'animale. Bollati Boringhiere, 2003. . "A potência do pensamento". Trad. de Carolina Pizzolo Torquato. Revista do Departamento de Psicologia da Universidade Federal Fluminense. ISSN 0104-8023, vol.18, n.1. Niterói jan./junho 2006.

AMOROSO, Maria Betânia. "Retratos-relâmpagos. Despedida e comemoração". Revista de Estudios Portugueses, v. 10, 2010.

ANDRADE, Carlos Drummond de. "Antonio Conselheiro". In: Carlos \& Mário. Correspondência completa entre Carlos Drummond de Andrade (inédita) e Mário de Andrade. Pref. e notas de Silviano Santiago. Ed. e pesquisa iconográfica de Lélia Coelho Frota. Rio de Janeiro: Bem-te-vi, 2002.

Poesia completa. Rio de Janeiro: Editora Nova Aguilar. 2002.

ANDRADE, Mário de. "A poesia em pânico" (1939). In: MENDES, Murilo. Poesia completa e prosa. Rio de Janeiro: Nova Aguilar, 1994. 
"Mestres do passado". In: BRITO, Mario da Silva. História do

modernismo brasileiro. 2. ed. Rio de Janeiro: Civilização Brasileira, 1964, p. 253-254.

ANTELO, Raúl. "Visão e pensamento. Poesia da voz”. In: ANTELO, Raúl (org.) Crítica e fiç̧ão. Florianópolis: Ed. Pallotti, 2006.

. "Murilo, o surrealismo e a religião". In: Boletim de Pesquisa NELIC. v.

6, n. 8/9, 2006. [Poesia: Passagens e impasses]. "A mesa: direito e avesso". Conferência apresentada no XXVII encontro da Associação Nacional de Pós-graduação em Letras e Linguística. Niterói, 10 a 13 de julho de 2012

ARAÚJO, Laís Corrêa de. Murilo Mendes ensaio crítico, antologia, correspondência. São Paulo: Perspectiva, 2000.

BARBOSA, João Alexandre. João Cabral de Melo Neto. São Paulo: Publifolha, 2001. - A imitação da forma. São Paulo: Perspectiva, 1975.

BARTHES, Roland. “La métaphore de l'CEil ». Critique, n. 195-196, 1964.

BATAILLE, Georges. História do olho. Trad. de Eliane Robert Moraes. São Paulo: Cosac Naif, 2003.

. “A representação de Numância". Trad de Fernando Scheibe.

Revista Acéfalo III - IV, Boletim de Pesquisa NELIC v. 9, nº 14. 2009.2.

BENJAMIN, Walter. Origem do drama barroco alemão. Trad. de Sérgio Paulo Rouanet. São Paulo: Brasiliense, 1984. Magia e técnica. Arte e política. Trad. de José Carlos M. Barbosa. São Paulo: Brasiliense, 1994.

"A tarefa do tradutor". Trad. de Susana Kampf Lages. In: HEIDERMANN, Werner (org.), Clássicos da teoria da tradução. Florianópolis: UFSC, Núcleo de Tradução, 2001.

BOSI, Alfredo. História concisa da literatura brasileira. São Paulo: Cultrix, 1985.

CANDIDO, Antonio. “Poesia ao Norte”. Colóquio Letras, 157/158, Lisboa, jul. 2000.

CARVALHO, Ricardo Souza de. A Espanha de João Cabral e Murilo Mendes. São Paulo: Editora 34, 2011.

DUMÉZIL, Georges. Mito y epopeya III. Historias romanas. Trad. de Sergio M. Baez. México: Fondo de Cultura Económica, 1996.

FOUCAULT, Michel. As palavras e as coisas. Trad. de Salma Muchail. São Paulo: Martins Fontes, 1999. 
GARCIA, Wladimir. O cometa e o bailarino. Florianópolis, UFSC, 1990. Tese de doutorado. Programa de Pós-Graduação em Literatura, Universidade Federal de Santa Catarina, Florianópolis, 1990.

GUIMARÃES, Julio C. "Cabral falando" Teresa: Revista de Literatura Brasileira. São Paulo, FFLCH-USP/Editora 34, n. 3, 2002.

DIDI-HUBERMAN. Quand les images prennent position. Minuit, 2009. (Trad. espanhola) Cuando las imágenes toman posición, Madrid, Machado, 2008. . La ressemblance par contact. Paris: Les Éditions du Minuit, 2008. - Ante el tiempo. Trad. de Oscar Funes. Buenos Aires: Adriana Hidalgo, 2006. . O que vemos. O que nos olha. Trad. de Paulo Neves. São Paulo: Ed. 34, 1998.

JOYCE, James. Ulisses. Trad. de Antonio Houaiss. Rio de Janeiro: Ed. Civilização Brasileira, 2003.

LIMA, Luiz Costa. Lira e anti-lira. Mário, Drummond, Cabral. Rio de Janeiro: Civilização Brasileira, 1966.

MELO NETO, João Cabral. Poesia completa. Rio de Janeiro: Nova Aguilar, 2003.

MENDES, Murilo. Poesia completa e prosa. Rio de Janeiro: Nova Aguilar, 1994. - L'occhio del poeta. PICCHIO, Luciana Stegagno (Org.). Roma: Gangemi editore, 2001.

MOISÉS, Massaud. O simbolismo (1893-1902). São Paulo; Cultrix, 1969.

MOLINA, Ricardo. "Mundo y formas del cante". [Revista de Occidente, Madrid, 1963], Librería Al-Andalus, Granada-Sevilla, 1979.

NIETZSHE, F. Fragmentos póstumos. Trad. de Noéli Correia. Rio de Janeiro: Ed. PUCRio; São Paulo: Loyola, 2005.

PLOEGMAKER, Ruud. "Sthéfane Mallarmé e João Cabral”, em Gragoatá, n. 5, 2. sem. de 1998. Niterói.

VALÉRY, Paul. Oeuvres. Biblioteque de La pleiade. Paris : Gallimard, 1995. 